\title{
Studies on Bhartṛhari, 9: Vākyapadīya 2.119 and the Early History of Mīmāṃsā
}

\author{
Johannes Bronkhorst
}

Published online: 12 June 2012

(C) Springer Science+Business Media B.V. 2012

\begin{abstract}
This article argues that in early Mīmāmsā the view was current that there are objects in the world corresponding to all words of the Sanskrit language. Evidence to that effect is primarily found in passages from Bhartrihari's works, and in some classical Nyāya texts. Interestingly, Śabara's classical work on Mīmāṃsā has abandoned this position, apparently for an entirely non-philosophical reason: the distaste felt for the newly arising group of Brahmanical temple-priests.
\end{abstract}

Keywords Bhartṛhari · Mīmāṃsā $\cdot$ Śabara · Linguistic philosophy · Temple-priests

\section{Abbreviations}

ASS Ānandāśrama Sanskrit Series, Poona

DNC Dvādaśāranayacakra of Mallavādin. Edited, with the commentary Nyāyāgamānusāriṇī of Siṃhasūri Gaṇi Vādi Kṣamāśramaṇa, by Muni Jambūvijayajī, 3 parts, Bhavnagar: Sri Jain Atmanand Sabha, 1966, 1976, 1988

\footnotetext{
Preceding articles of this series have been published in the following periodicals and books: Bulletin d'Études Indiennes 6 (1988), 105-143 (no. 1: "L'auteur et la date de la Vrtti"); Studien zur Indologie und Iranistik 15 (1989), 101-117 (no. 2: "Bharț̣hari and Mīmāṃsā”); Asiatische Studien/Études Asiatiques 45 (1991), 5-18 (no. 3: "Bhartṛhari on sphoța and universals"); id. 46.1 (1992), 56-80 (no. 4: "L'absolu dans le Vākyapadīya et son lien avec le Madhyamaka"); id. 47.1 (1993), 75-94 (no. 5: "Bhartṛhari and Vaiśeșika"); Vācaspatyam: Pt. Vamanshastri Bhagwat Felicitation Volume (Pune, 1994, pp. 32-41; no. 6: "The author of the Three Centuries"); Annals of the Bhandarkar Oriental Research Institute 76 (1995 [1996]), 97-106 (no. 7: “Grammar as the door to liberation"); Journal of Indian Philosophy 27(1/2) (1999), 23-33 (no. 8: "prākrtta dhvani and the Sāmkhya tanmātras").
}

\footnotetext{
J. Bronkhorst ( $($ )

Université de Lausanne, Lausanne, Switzerland

e-mail: johannes.bronkhorst@unil.ch
} 
MīBh Mīmāṃsā Bhāṣya de Śabara (ASS 97)

NBh Nyāyabhāṣya of Pakṣilasvāmin Vātsyāyana, in the following edition: Nyāyadarśanam with Vātsyāyana's Bhāṣya, Uddyotakara's Vārttika, Vācaspati Miśra's Tātparyațīkā \& Viśvanātha's Vṛtti. Chapter I, section I critically edited with notes by Taranatha Nyaya-Tarkatirtha and chapters I-ii-V by Amarendramohan Tarkatirtha, with an introduction by Narendra Chandra Vedantatirtha. Calcutta: Metropolitan Printing \& Publishing House, 1936-1944

NV Nyāyavārttika of Uddyotakara. For the edition, see NBh

Vkp Bhartṛhari, Vākyapadīya, ed. W. Rau, Wiesbaden 1977

Bhartrhhari's Vākyapadīya contains the following two kārikās (Vkp 2.119-120):

asty arthaḥ sarvaśabdānām iti pratyāyyalakșanam/

apūrvadevatāsvargaị samam āhur gavādișu/l

prayogadarśanābhyāsād ākārāvagrahas tu yah̆/

na sa śabdasya viṣayah sa hi yatnāntarāśrayah̆//

These can be translated as follows:

They say that the characteristic of what is to be conveyed is that all words have things [corresponding to them]; this applies to [words] such as 'cow' as much as to [the words] apürva, devatā and svarga. The grasping of the form ( $\bar{a} k \bar{a} r a)$ as a result of repeatedly observing the use of a word, on the other hand, is not the realm of words, for it is based on a different effort.

Understood in this way, the first of these two kārikās draws attention to an opinion according to which the existence of a word guarantees the existence of the corresponding thing. The existence of the words apūrva, devatā and svarga guarantees that the corresponding things-Unprecedented Potency (apūrva), deities and Heaven-exist.

The second kārikā specifies that this corresponding thing is not a form $(\bar{a} k \bar{a} r a)$. This is a criticism of those who believe that words primarily (or even exclusively) denote forms. The thinkers whose opinion is here recorded do not agree, and this allows us to conclude that the things corresponding to words are individuals, not forms, and presumably not universals either. We will return to this point below.

This interpretation of Vkp 2.119-120 makes sense, and remains close to the text. It is also in agreement-or at any rate not in obvious disagreement-with the one surviving commentary on this passage, the one by Punyarāja. (The ancient $V r t t i$ on this passage has not survived.) Punyarāja explains the first pāda as follows: 
sarvaśabdānām aparāmrșțākāraviśeșam arthamātram vācyam iti kecid āhuh

I propose to translate this as follows:

Some say that the mere thing is denoted by all words, without consideration of the particular form. ${ }^{1}$

A passage in Bhartrihari's commentary on the Mahābhāṣa further supports this interpretation of $\mathrm{Vkp} 2.119$. It reads as follows ${ }^{2}$ :

atha vārthopalabdhị śabdāstitvānumānam. na hi kaścid artho 'śabdo 'sti. tatra yathaiva svargāpūrvadevatāśabdā upalabhyamānā atyantāparidrștānām astitvānumānam evam kim na gṛhyate 'rtha upalabhyamānah śabdāstitvasyānumānam iti.

Or rather, the perception of a thing is the means by which we are able to infer that the [corresponding] word exists, because there is nothing that has no word [to denote it]. Just as the words svarga, apūrva, and devatā, when perceived, enable us to infer that things that are absolutely imperceptible exist, in the same way, does not a thing when perceived enable us to infer that the [corresponding] word exists?

The remark about svarga, apürva and devatā serves as comparison in this passage, and does not therefore embody an alternative hypothesis but rather a known fact: these three words enable us to infer the existence of things that are absolutely imperceptible. Here, clearly, the words svarga, apürva and devatā are taken to refer to real objects, whose existence is shown by the existence of these words.

All these passages seem to indicate that Bhartrhari was acquainted with the idea that the parallelism between (Sanskrit) words and things is complete: not only are there words for all things, there are also things corresponding to all (Sanskrit) words. This idea is in agreement with a verse from the first book of the Vākyapadīya, which reads (Vkp 1.124):

śabdasya parịnāmo 'yam ity āmnāyavido viduh/

chandobhya eva prathamam etad viśvam pravartate/l

The knowers of tradition know that all this is a transformation of the word.

This universe arises originally out of the Vedas.

The second half of the above observation- "there are things corresponding to all (Sanskrit) words"-will occupy us in this article. It is the most startling half, at least from a modern point of view. It is demonstrably untrue for the languages we now use, which have many words-such as "Martian", "angel"- that do not refer to any existing entities, not at least according to an important part of their users. It

\footnotetext{
1 The use of arthamātra, which can mean "thing in itself", suggests that the object intuited by perception without conceptual construction (avikalpaka) is meant. Cp. Dignāga's Pramānasamuccaya: yoginām apy āgamavikalpāvyatikīnnam arthamātra-darśanam pratyakșam "The yogin's intuition which is not associated with any conceptual construction of the ägama (the authoritative words of the teachers) and which apprehends only a thing in itself is also perception" (Hattori 1968, pp. 27, 94; Steinkellner 2005, p. 3 1. 11).

2 Bronkhorst (1987, p. 28 1. 7-10); tr. Unebe (2011, pp. 547-548, modified).
} 
presupposes a language that is stable in time, and which has no place for new words coined by its users. This may very well be the image that many Sanskrit users had of their language.

We will see below that there are, and have been, other interpretations of Vkp 2.119. For the time being we stay with the present interpretation, and observe that the notion according to which the existence of words tells us something about the existence of the things named is not unknown to other Indian philosophical texts. We find it in Buddhist thought, very clearly in Nāgārjuna's Vigrahavyāvartanī 9, which states it in so many words: nāma hi nirvastukam nāsti "for there is no noun without corresponding thing". The notion is also fundamental to the ontological scheme of the Vaiśeșika philosophy, of which it is one of several underlying axioms. $^{3}$

The notion appears, furthermore, in some texts belonging to the Nyāya school of philosophy. Consider the following passage from Vātsyāyana's Nyāyabhāṣya. It reads ${ }^{4}$ :

The word is a means of inference; it is not a distinct means of knowledge. - Why? Because the object of a word is inferred. - How so? Because it is not apprehended by means of perception. A sign-possessing object, though not apprehended, comes to be known through a knowledge of the sign; it follows that [the sign] is a means of inference. Likewise, an object, though not apprehended, comes to be known through a knowledge of the word by which it is designated. Therefore, the word is a means of inference. There is also the following reason: ... when a means of knowledge is distinct, apprehension involves two distinct processes. For apprehension takes place one way in the case of inference and another way in the case of analogy. ... But in the case of word and inference, apprehension does not involve two processes. The process involved in inference is the same as the process involved in word. Since there is no difference, the word is a means of inference. ... One grasps an object through verbal knowledge when the relation between a word and the object connected to it is well known, just as one grasps an object through inferential knowledge when the relation between an inferential sign and the object possessing the sign is well known.

This passage gives expression to a point of view with which the author of the Nyāyabhāṣya is not in agreement. This is an advantage in disguise, because his

\footnotetext{
3 Bronkhorst (1992, 2011, pp. 23-29).

${ }^{4}$ NBh 2.1.49-51 (pp. 534-535): śabdo 'numānam na pramāṇāntaram. kasmāt? śabdārthasyānumeyatvāt. katham anumeyatvam? pratyakșato 'nupalabdheh. yathānupalabhyamāno lingī mitena lingena paścān mīyata ity anumānam. evam mitena śabdena paścān mīyate 'rtho 'nupalabhyamāna ity anumānam śabdah. itaś cānumānam śabdah. ... pramānāntarabhāve dvipravrttir upalabdhih. anyathā hy upalabdhir anumāne 'nyathopamāne .... śabdānumānayos tūpalabdhir advipravrttir yathānumāne pravartate tathā śabde 'pi. viśeșābhāvād anumānam śabda iti. .... sambaddhayoś ca śabdārthayoh sambandhaprasiddhau śabdopalabdher arthagrahaṇam yathā sambaddhayor lingalinginoh sambandhapratītau lingopalabdhau lingigrahanam iti.
} 
rejection of this point of view provides us with some elements that are not clearly expressed in the passage itself. This rejection reads ${ }^{5}$ :

It is not because of words on their own that one believes in the existence of imperceptible objects such as "heaven," "the Apsarases," "the Northern Kurus," "the seven continents," "the ocean," or "the shape of the world"; rather, one believes [in their existence] because they have been spoken of by trustworthy people. Otherwise one would not believe in them. Inference, however, is not like this.

It is clear from this response that the author of the criticized passage believed that various religious and mythological expressions correspond to reality simply because those expressions are part of the Sanskrit language. Vātsyāyana rejects this belief but shows, by doing so, that some held it.

It is not clear from the above passages whether Vātsyāyana believed that, de facto, all Sanskrit words correspond to items in the real world. This is still conceivable, because the words of the Sanskrit language were created by a trustworthy person, viz. God himself. This would mean that the word would not by itself be a means of inference, but the knowledge that God had created it would be a reason to accept that the item denoted exists. And indeed, under sūtra 1.1.4 Vātsyāyana states ${ }^{6}$ : "There are as many naming words as there are things."

Uddyotakara's Nyāyavārttika, a commentary on the Nyāyabhāsya, and therefore a subcommentary on the Nyāyasūtra, gives more detailed information. Sūtra 1.1.7 introduces the notion of reliable-teaching (apta-upadeśa). The rules of Sanskrit grammar allow of two ways to analyze this compound: "teaching by a reliable person" or "teaching that is reliable". The Nyāyabhāsya opts for the former interpretation, but Uddyotakara's Nyāyavārttika introduces an opponent who disagrees, for the following reason ${ }^{7}$ :

[If we only accept teaching by a reliable person,] there would be no teaching concerning such entities as svarga, apūrva and devata, because these things are beyond the senses. If reliability is the direct perception of a thing, there would be no discourse informing us about such entities as svarga, apūrva and devata , since no one can see them. For this reason it is appropriate [to analyze the compound] as "teaching that is reliable" rather than as "teaching by a reliable person".

Uddyotakara rejects this position, but his very rejection suggests that there were people who held that the presence in the Sanskrit language of words such as svarga, apūrva and devata proves that such things exist. We will return to this issue below.

\footnotetext{
5 NBh 2.1 .52 (p. 536): svargaḥ apsarasah uttarāh kuravah sapta dvīpāh samudro lokasamniveśa ity evamāder apratyakṣasyārthasya na śabdamātrāt pratyayah, kim tarhi? āptair ayam uktah śabda ity atah sampratyayah, viparyayeṇa sampratyayābhāvāt. na tv evam anumānam iti. .

${ }^{6} \mathrm{Nbh} 1.1 .4$ (p. 109): yāvadartham vai nāmadheyaśabdāh. Note that Vātsyāyana, following the sūtra, does not maintain that all cognition is expressible in words.

${ }^{7} \mathrm{NV} 1.1 .7$ (p. 174): svargāpūrvadevatādișūpadeśo na prāpnoti at̄̄ndriyatvāt. yadi sākșātkaraṇam arthasyāptih, svargāpūrvadevatādīn na kaścit paśyatīti tatpratipādako vyavahāro na syāt. tasmād āptaś cāsāv upadeśaś ceti yuktam, nāptasyopadeśa iti.
} 
Does it follow from the passages considered that for Uddyotakara things such as svarga, apūrva and devatā do not exist? Another passage in his Nyāyavārttika shows that this not the case. Indeed, we learn from it that Uddyotakara does believe that there are things corresponding to all words (na hy ekam padam nirarthakam paśyamah). This other passage has been discussed in another publication (Bronkhorst 2011, pp. 119-120), but merits repetition here ${ }^{8}$ :

Here, to begin with [one must say] that the two (sic!) words (pada) "the soul does not exist" ( a a asti $\bar{a} t m \bar{a})$ contradict [each other]: the word "soul" (ātmā), [even when placed] in syntactic agreement with the words "does not exist" (na asti), does not communicate the non-existence of the soul. For with the word "soul," one expresses [its] existence, and with "does not exist," its negation; the [very] thing denied in one place appears in the other. For example, the word "pot," in syntactic agreement with "is not [there]" (na asti), cannot communicate the non-existence of the pot; rather, it denies [its presence] in a particular place or at a particular time. [The sentence] "the pot is not" (nāsti ghatah) denies [its presence] in a particular place, [as in the example] "it is not in the house"; or it denies [its presence] at a particular time, [as in the examples] "it is not [there] now," "it was not [there] before," "it will not be [there] later." None of these negations are possible for someone who does not accept the existence of the pot. Likewise, [in the sentence] "the soul does not exist," is the soul denied with respect to a particular place or with respect to a particular time?

Uddyotakara continues ${ }^{9}$ :

He who denies the soul [altogether] must specify the object of the word "soul."

\section{Indeed, we do not see a word without an object.}

We may conclude that Uddyotakara, as Vātsyāyana before him, did indeed believe that all Sanskrit words (or at least all nouns) designate something that exists in the "outside" world. In this respect they agreed with Bhartrinari (or at least the persons referred to by Bhartrhari in Vkp 2.119) and with the thinkers they criticize in the passages considered. They criticized these thinkers because they were not ready to look upon the word as a means of inference, but they agreed with them in accepting a full correspondence between words and things.

Who were the thinkers criticized by Uddyotakara, and presumably by Vātsyāyana and Bhartṛhari? The distinction between "teaching that is reliable" and "teaching by a reliable person" must be understood in the light of the belief held

\footnotetext{
${ }^{8}$ Uddyotakara, Nyāyavārttika introducing 3.1.1 (p. 6991.1 ff.): tatra nāsty ātmeti pade tāvad vyāhanyete, nāstiśabdasamānādhikarano 'yam àtmaśabdo nātmano 'sattvam pratipādayati. kị kāranam? ātmeti sattvam abhidhīyate, nāstīti tasya pratiședhah, yac ca yatra pratișidhyate tat tasmād anyatrāsti, yathā nāstinā samānādhikarano ghațaśabdo na ghațābhāvam pratipādayitum śaknoti, api tu deśakālaviśeșe pratiședhati. nāsti ghața iti deśaviśeșe vā pratiședho gehe nāstīti, kālaviśeșe vā pratiședha idānīm nāstīti prān nāsti ürdhvam nāstīti. sarvaś cāyam pratisedho nānabhyupagataghațasattvasya yuktah. tathā nāsty ātmeti kim ayam deśaviśeșe pratișidhyate atha kālaviśeșe iti.

9 Ibid., p. 701 1. 5-6: ātmapratiṣedham ca kurvāṇenātmaśabdasya viṣayo vaktavyah. na hy ekam padam nirarthakam paśyāmaḥ.
} 
by some in classical India that the Veda has no author. The Veda, according to those who held this belief, contains reliable teaching, but is not the teaching of or by one or more reliable persons. The belief in the authorlessness of the Veda is characteristic of Mīmāṃsā, the school of Vedic interpretation. This suggests that Uddyotakara's opponent is a Mīmāṃsaka.

This impression is confirmed by the presence of apūrva in the list of items enumerated. Apūrva is a technical term of Mīmāmsā, which designates the Unprecedented Potency responsible for the future outcome of sacrificial activity.

We are entitled to conclude that Uddyotakara and Bhartrhari, and perhaps Vātsyāyana too, ${ }^{10}$ refer to a position that was or had been held by Mīmāṃsakas.

However, these Mīmāmsakas differed from Śabara, the author of the surviving Mìmāmsābhāṣya (or Śäbara-Bhāṣya). This text was composed around the middle of the first millennium CE, roughly during the time in which also Bhartrhari lived and wrote. There are reasons to think that Bhartrhari was not yet acquainted with Śabara's Bhāṣya, or that he ignored it. He may have used earlier Mīmāmsāa works, most notably the Vrtti of Bhavadāsa. ${ }^{11}$ This is to be kept in mind in what follows.

Śabara agrees in principle with the idea that the Veda is always correct ${ }^{12}$ :

It is a contradiction to say "[the Vedic word] speaks" and "incorrectly". When one says "it speaks", this means "it makes known", that it is the cause that [the thing] is known.

However, Śabara applies this idea only to injunctions. He does not, for example, claim that the occurrence of the words svarga, apūrva and devatā in the Sanskrit language (more precisely: in the Veda) constitutes proof that the corresponding entities must exist. Quite on the contrary, he comes close to denying the existence of two of them (heaven and deities). And in order to prove the existence of apürva, he resorts to an altogether different line of reasoning.

Consider the case of $\operatorname{svarga}^{13}$ :

\footnotetext{
10 The evidence provided by Vâtsyāyana is less decisive: the arguments that allow us to identify Uddyotakara's opponent as a Mīmāṃsaka (interpretation of āpta-upadeśa; apūrva) cannot be use to identify Vātsyāyana's opponent. Vātsyāyana's opponent, moreover, explicitly states that the word is a means of inference. Taber (1996, pp. 22-23) may therefore be right in thinking that Vātsyāyana rather criticizes the Buddhist Dignāga or those who had been influenced by his thought. Note however that already Bhartrhari-in the passage from his commentary on the Mahābhāşya which we studied abovespeaks of inference as the means to conclude that imperceptible things exist on the basis of words such as svarga, apūrva, and devatā; Bhartṛhari lived before Dignāga. We cannot exclude that Vātsyāyana criticizes Bhartṛhari (or his Mìmāmnsā source?).

11 Bronkhorst (1989).

12 MīBh on sūtra 1.1.2 (Frauwallner 1968, p. 16 1. 18-19): vipratișiddham idam abhidhīyate "bravīti ca vitatham ca" iti. bravīti ity ucyate 'vabodhayati, budhyamānasya nimittam bhavati iti. Cf. Bronkhorst (1997, p. 367).

13 MīBh on sūtra 6.1 .1 (p. 177 1. 9-21): nanu svargaśabdo loke prasiddho viśiște deśe. yasmin noṣnam, na śìtam, na kṣud, na tṛṣnā, nāratih, na glānih, punyakṛta eva pretya tatra gacchanti nānye. atrocyate. yadi tatra kecid amṛtvā na gacchanti tata āgacchanty ajanitvā vā na tarhi sa pratyakșo deśa evamjātīyakah. nāpy anumānād gamyate, nānyena. nanu cānye siddhā kecid dṛștavantah te cākhyātavanta iti cet. na tatra pramāṇam asti siddhā evamjātīyakāh santi te ca dṛșțācakșīrann iti. tasmād evamjātīyako deśa eva nāsti.
} 
[Objection:] The word 'heaven' is well known in the world to refer to a specific place, in which there is no heat, no cold, no hunger, no thirst, no dissatisfaction, no depression, and where those who have done good deeds go after death, but no others.

The answer is as follows. If no people go there without having died, or come from there without having been born, such a place is not accessible to the senses. Nor is it known from inference, nor by any other [means].

[Objection:] Some people with occult powers, different [from us], have seen [heaven] and have talked [about it].

[Answer:] There is no proof that there are such people with occult powers, and that they, having seen [heaven], talk [about it]. No such place therefore exists. [Objection:] We learn from [people in] the world, from stories and from the Veda that there is such a place called 'heaven'.

[Reply:] This is not [acceptable]. The words of people constitute no proof, because they have no contact with such a place. Nor should stories be heeded, because they have been composed by human beings. Even the Vedic stories about heaven do not occur in injunctions. They are eulogies to be construed with an injunction different from them.

Two things strike us in this passage. First of all, Śabara does not as much as mention the argument according to which the existence of heaven is proved by the existence of the word 'heaven'. Second, Śabara comes close to rejecting the notion of heaven altogether.

Śabara's discussion of deities confronts us with a similar situation. Śabara first lets an opponent speak who claims that deities play a role in connecting sacrifice with its fruits. ${ }^{14}$ Śabara rejects all the opponent's arguments under sūtra 9.1.9, and leaves us with the impression that he puts the very existence of deities into doubt. There is no question here of Śabara saying that the word devata itself proves the existence of deities.

As a matter of fact, Śabara's elaborate discussion reminds us that in his form of Mīmāmsāa , the Veda does not provide information about entities: only injunctions must be taken literally, and everything else has to be read along with and in the light of those injunctions. It follows that the Veda contains no reliable teaching as to the existence of deities, heaven and apürva.

Śabara discusses apūrva under sūtra 2.1.5. This time he does not reject the existence of this entity, but presents arguments to show its existence. Among these arguments we do not find the one that claims that the word apürva proves its existence.

What can we conclude from all this? It seems beyond doubt that, leaving aside the Buddhists, there were Brahmanical thinkers in India who held that the occurrence of a word in Sanskrit (more precisely: in the Veda) is proof of the

\footnotetext{
Footnote 13 continued

nanu ca lokād äkhyānebhyo vedāc cāvagamyate, deśa evamjātīyakah svarga iti. tan na. purușānām

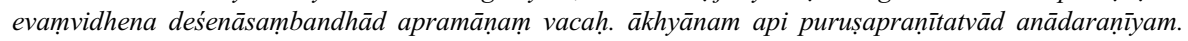
vaidikam api svargākhyānam vidhiparam nāsty eva. bhavati tu vidhyantareṇaikavākyabhūtam stutiparam.

${ }^{14}$ MīBh on sūtra 9.1 .8 (pp. 74 1. 16-75 1. 3).
} 
existence of the corresponding entity. This position is still known to, and presumably held by, the Naiyāyikas Vātsyāyana and Uddyotakara, and of course to Bhartrihari. It had also been held by Mīmāmsakas, but not by the followers of Śabara (or by Śabara himself). Perhaps they were Mīmāmsakas who preceded Śabara. We know from Jayanta Bhața's Nyāyamañjarī that this author was still aware of "old Mīmāmsakas" (vṛddhamìmāmsaka) who held opinions different from the "followers of Śabara" (śäbara). ${ }^{15}$ Perhaps Bhavadāsa was one of these earlier Mīmāmsakas. Śabara, however, abandoned this position.

Our conclusion thus far is confirmed by a discussion at the beginning of the Śäbara-Bhāsya. This discussion concerns the meaning of the word dharma, a crucial term in Mīmāmsāa. Based on what ground do we have knowledge of dharma? Three sūtras (1.1.3-5) deal with this issue, and interestingly, Śabara provides two altogether different commentaries on these three sūtras. The first commentary is short, and amounts to this that the word (i.e., the word dharma) is the ground on which the knowledge of dharma is based. The second commentary is long, and has been taken, with acknowledgment, from a commentator about whom we know no more than that Śabara calls him Vrttikāra ("commentator"). It seems safe to think that the first commentary was the traditional one. The second commentary, the one attributed to the Vrttikāra, on the other hand, takes on all sorts of new ideas, and strays considerably from the sūtras it is supposed to explain. It contains a number of remarks that are of interest in our present context.

Consider first the presumably traditional explanation of the sūtras. Śabara points out, under sūtra 1.1.4, that perception (pratyakșa) cannot be the ground on which our knowledge of dharma is based. Introducing sūtra 1.1.5, he then adds that inference (anumāna), analogy (upamāna), presumption (arthāpatti) and absence $(a b h \bar{a} v a)$ cannot be its cause either, because these are preceded by perception. In his comments on that sūtra he tells us what its ground is ${ }^{16}$ : "The eternal link of the word with its object is the ground on which that dharma, which is of the nature of the Agnihotra sacrifice and so on, unknown by means of perception etc., is based." $\mathrm{He}$ explains this in the following lines ${ }^{17}$ :

For it is instruction. 'Instruction' (upadeśa) is what we call the pronouncement of specific words. And this knowledge does not go wrong. For this knowledge, once arisen, does not change into its opposite. And of knowledge that, once arisen, does not change into its opposite one cannot say "it is not like this", "it is not as it is known", "it is as it is not known". One would have in that case one thing in one's mind, and something else in one's speech. From someone

\footnotetext{
15 Jayanta Bhaț̣a, Nyāyamañjarī p. 664: vṛddhamīmāmsakāh yāgādikarmanirvartyam apūrvam nāma dharmam abhivadanti yāgādikarmaiva śābarā bruvate. Cf. Bronkhorst (1989, p. 113 [384]).

${ }^{16}$ Frauwallner (1968, p. 24 1. 5-6): autpattikaḥ śabdasyārthena saṃbandhas tasya agnihotrādilakșaṇasya dharmasya nimittam pratyaksādibhir anavagatasya.

17 Frauwallner (1968, p. 24 1. 7-14): upadeśo hi bhavati. upadeśa iti viśiștasya śabdasya uccāraṇam. avyatirekaś ca bhavati tasya jñānasya. na hi tad utpannam jñānam viparyeti. yac ca nāma jñānam utpannam na viparyeti, na tac chakyate vaktum "naitad evam" iti, "yathā vijñâyate, na tathā bhavati"; "yathaitan na vijñāyate, tathaitad" iti. anyad asya hṛdaye, anyad vāci syāt. evam vadato viruddham idam avagamyate "asti nāsti ca" iti. tasmāt tat pramāṇam, anapekșatvāt. na hy evam sati pratyayāntaram apekșitavyam puruṣāntaram vā.
} 
who speaks like that one would learn contradictory things, viz., "it is" and "it is not". It is therefore a means of cognition, because it is independent. For, such being the case, no other knowledge will be required, nor another person.

In other words, on the basis of the word dharma we know that dharma exists.

The second commentary on sūtras 1.1.3-5-the so-called Vrttikāra-grantha, and not therefore by Śabara-is harder to interpret with confidence. On the link between words and things the Vrttikāra says the following ${ }^{18}$ : "The link, not made by humans, of the word with its object is the [cause of] knowledge of the thing of the nature of the Agnihotra sacrifice and so on (i.e. of dharma) unknown by means of perception etc." This, of course, is close to what Sabara had said. But it is not certain that it means quite the same thing, for the Vrttikāra adds ${ }^{19}$ : "In this way there is correct knowledge that is of the nature of an injunction." It appears that the knowledge directly derived from words here only concerns injunctions, not the existence of items for which there is a Sanskrit word. The Vrttikāra adds a further explanation, as follows ${ }^{20}$ :

If the link were to have been made by humans, the knowledge could be suspected of being incorrect, because it would then be the knowledge of someone else. But if the word itself speaks, how could it be incorrect? In that case the knowledge does not come from another person. When one says "he speaks", this means "he makes known", that he is the cause that [the thing] is known. If, because the word itself is the cause, one understands of one's own, how could it state a falsehood of the form "it is not like that"?

I am not sure whether this throws further light on the Vrttikāra's intentions. The then following lines do, and they show that injunctions and nothing else were on his mind. We read here, for example, "An injunction does not create a doubt of the kind 'it may be the case, or not", ${ }^{21}$ contrasting the injunction with items of information one may obtain through other means of cognition. The passage concludes with an unambiguous remark: "It follows that the dharma is exclusively of the nature of injunctions." ${ }^{, 22}$ Almost the same remark is repeated later on in the Vrttikära-grantha ("It follows that the dharma is exclusively of the nature of injunctions and nothing

\footnotetext{
18 Frauwallner (1968, p. 34 1. 15-17): apauruṣeyah śabdasyārthena sambandhas tasya agnihotrādilakșaṇasya arthasya jñānam pratyakșādibhir anavagamyamānasya.

19 Frauwallner (1968, p. 17): tathā ca codanālakșaṇah samyakpratyaya iti.

${ }^{20}$ Frauwallner (1968, p. 34 1. 17-22): paurușeye hi sati sambandhe yah pratyayah, tasya mithyābhāva àsaṅkyeta. parapratyayo hi tadā syāt. atha śabde bruvati katham mithyā iti? na hi tadānìm anyatah purușād avagamah. "bravīti" ity ucyate "avabodhayati, budhyamānasya nimittam bhavati" iti. śabde cen nimittabhūte svayam avabudhyate, katham vipralabdham brūyān "naitad evam” iti. See also footnote 12, above.

21 Frauwallner (1968, p. 34 1. 22-23): na cāsya codanā "syād vā na vā" iti sāmśayikam pratyayam utpādayati.

22 Frauwallner (1968, p. 36 1. 4-5): tasmāc codanālakșana eva dharmah. The reason justifying this conclusion appears to be that only injunctions cannot possibly be contradicted by other means of knowledge, but the passage is obscure.
} 
else"). ${ }^{23}$ The accent has clearly shifted from knowing dharma to knowing that dharma is exclusively of the nature of injunctions.

Interestingly, the question of deities and other unobservable entities comes up in the Vrttikāra-grantha, too. But far from using words like devatā to prove that deities must exist, the Vrttikāra uses them to prove that words have not been created by a name-giver ${ }^{24}$ : "In the case of unobserved things, such as deities and so on, the giving of a name is pointless and impossible." This line does not tell us whether the Vrttikāra believed that deities exist, for deities cannot be observed, whether they exist or not.

One does have the impression that in these passages the Vrttikāra avoids the issue to some extent. He yet engages in a discussion with thinkers-probably Cārvākas ${ }^{25}$ - who are very explicit about their denial of the necessary existence of things for which there is a word. It is in this discussion that he is forced to clarify his position: "We do not designate the word 'I', when used, as ground for [the existence of] some other object, but rather the recognizing knowledge that is different from the word." 26 In other words, we do not claim that the soul exists because there is a word, 'I', that refers to it. Here, then, the Vrttikāra comes out in the open: he draws no ontological conclusions from the existence of words. We know that Sabara followed him in this.

According to Śabara, the sole referent of a word is the $\bar{a} k r t i$ 'form' ${ }^{27} \bar{A} k r t i$ is a synonym of $\bar{a} k \bar{a} r a$, the term used by Bhartrhari to state that its "grasping as a result of repeatedly observing the use of a word is not the realm of words, for it is based on a different effort". In other words, Bhartrihari refers to an opinion according to which $\bar{a} k r t i$ is not the sole referent of a word. Worse, $\bar{a} k r t i$ is not a referent at all; it is grasped by means of a different effort altogether.

Śabara's Bhāsya is aware of the position according to which words refer to individuals, not to forms or universals. Śabara criticizes this position under sūtra 1.3.30, but not without giving his opponent occasion to defend it. The opponent most notably explains how it is possible that we also understand the universal (sāmānya) when hearing a word. His answer: The form $(\bar{a} k r t i)$ is a sign of the individual, but only the individual is the referent of the word. ${ }^{28}$

This same opponent is given more space under sūtra 1.3.33. He there argues that the word designates an individual without designating its universal and specifics, but

\footnotetext{
${ }^{23}$ Frauwallner (1968, p. 48 1. 13-14): tasmāc codanālakșaṇa eva dharmo nānyalakșaṇah. The reason here is that only injunctions are independent of other people and of other cognitions.

24 Frauwallner (1968, p. 48 1. 7): anupalabdhe ca devatādāv arthe 'narthakam sajñākaranam aśakyam ca.

25 Bronkhorst (2007, p. 363 f).

${ }^{26}$ Frauwallner (1968, p. 56 1. 7-9): na vayam “aham” itīmam śabdam prayujyamānam anyasmin arthe hetutvena vyapadiśämah, kị̣ tarhi śabdād vyatiriktạ pratyabhijñāpratyayam.

27 MīBh on sūtras 1.3.30-35 (pp. 235-268). On the precise interpretation of ākrti, see the following note.

28 MīBh on sūtra 1.3 .30 (p. 244 1. 2-4): katham sāmānyāvagatir iti cet. vyaktipadārthasyākṛtiś cihnabhūtā bhavișati, ya evamākrtikah, sa gaur iti. yathā yasya daṇ̆o 'sti, sa daṇ̂̄iti, na ca dandavacano daṇịśabdah. evam ihāpi. In other words, one grasps the form "based on a different effort". Note further that this passage uses sāmānya 'universal' and ākrti 'form' as synonyms, and cp. Deshpande (1992, pp. 19-22) and Scharf (1990, p. 249 ff.).
} 
an individual nonetheless that is the substrate of a universal and of specifics. ${ }^{29}$ Moreover, in spite of the fact that no universal and no specifics are denoted, a word cannot designate just any individual-the word 'cow' does not denote a horse, because it is the nature of the denotative power of words to apply to certain individuals, not to others. $^{30}$

The question we have to raise, but cannot answer with certainty, is whether the "old Mīmāmsakas", i.e., the Mīmāṃsakas preceding the Vṛttikāra and Śabara, agreed with Bhartrhari also in this further point: Apart from believing that there would be an existing thing corresponding to every Sanskrit word, did they also believe that words denote individuals, not forms? An affirmative answer to this question looks plausible, but does not rest on any evidence known to me beyond Bhartrhari's verse.

Assuming that the above attempt at reconstructing early Mīmāṃsā is correct, is it possible to find out why Śabara, and the Vrttikāra before him, introduced so radical a change into Mīmāmsā thinking? A close reading of Śabara's discussion of the existence of deities (devatā) may help us find an answer. A few times in his commentary on sūtra 9.1.9 Śabara speaks of deva- or devatā-paricārakas (sometimes just paricārakas). He tells us various things about these "attendants of the deity". The attendants of the god derive their maintenance from what has been donated to the deity. ${ }^{31}$ The context reveals that what is at stake are devagrämas and devakșetras, villages and fields given to the deity. Śabara points out that no deity is involved in such deals, and that he who is entitled to use the village or field concerned, not the deity, is its owner. ${ }^{32}$ Śabara further informs us that people believe that the attendants use the riches that belong to the deity in accordance with its wishes, but it is as clear as daylight to Śabara that the attendants act in accordance with their own wishes. ${ }^{33}$

The context in which these passages occur deals with the questions whether deities have bodies, whether they can eat, and whether they can own property. Śabara's answer is three times no. The passages suggest that more than a mere theoretical issue is at stake. Śabara is obviously critical of those who make a living out of the deities, by being their attendants, feeding them, and looking after their property. These attendants were in all probability Brahmanical temple-priests, ${ }^{34}$ and

\footnotetext{
${ }^{29}$ MīBh on sūtra 1.3 .33 (p. 247 1. 2-4): vyaktivacanaś ca śabdo na sāmānye, na viśeșe vartate. teșām tv āśrayam evābhidadhāti, tena vyaktyantare vṛttir adoșah.

${ }^{30} \mathrm{MīBh}$ on sūtra 1.3 .33 (p. 247 1. 12-15): evam tarhi śakteḥ svabhāva eșaḥ, yat kasyāmcit vyaktau vartate, kasyāmcin na. yathā - agnir uṣnah, udakam śītam, evam etad bhaviṣyatīti.

31 MīBh on sūtra 9.1 .9 (p. 80 1. 1-2): devaparicārakāṇām tu tato bhṛtir bhavati devatām uddiśya yat tyaktam.

32 MīBh on sūtra 9.1 .9 (p. 79 1. 25-26): yo yad abhipretam viniyoktum arhati tat tasya svam. na ca grāmam kṣetram vā yathābhiprāyam viniyunikte devatā.

${ }^{33}$ MīBh on sūtra 9.1 .9 (p. 80 1. 5-12): tatrāhuh. vacanaprāmāṇyād evāsyeśānatā 'vagamyate, yad eva lokā arthān viniyuñjate tad devatābhiprāyād evety adhyavasyāma iti. tan na. pratyakșāt pramāṇād devatāparicārakānām abhiprāya ity avagamyate. sa na śakyate bādhitum. ye 'pi devatām īsānām varṇayanti te 'pi nāpahnuvate paricārakāṇām abhiprāyam. kị̣ cāhuh. tathā devatā karoti yathā paricārakānām abhiprāyo bhavatīti. na ca sa ìsāno bhavati yah parābhiprāyam anurudhyate, yasya na svābhiprāyād viniyogo bhavati.

34 This is indeed how Ganganatha Jha (1933, p. 1436) translates paricāraka.
} 
the contempt in Brahmanical circles for temple-priests is well known and has survived until today. In Śabara's days they may have been a relatively new phenomenon, so much so that Śabara felt called upon to reject whatever justification for their occupation the Brahmanical temple-priests may have invoked. Their principal justification was, obviously, the existence of deities that needed to be fed and looked after. ${ }^{35}$

Śabara's dislike for this new development was evidently strong enough to induce him, or perhaps rather the Vrttikāra, to introduce major changes in Mīmāṃsā thinking. Before these two, Mīmāṃsā presumably did not object to the existence of heaven and deities, and what is more: it accepted the existence of everything for which there is a word in the Sanskrit language. With the Vrttikāra and Sabara this principle had to be abandoned. The existence of things for which the Sanskrit language had a word was no longer guaranteed by that very fact, and arguments, or reliable testimony, were henceforth required.

The reason for this profound philosophical change, it may be recalled, appears to have been a socio-religious development in the subcontinent. Increasingly, deities came to be venerated in temples, and worse: more and more temple-priests claimed Brahmanical status (or the other way round: more and more Brahmins took up the job of temple-priests). This was an obvious threat to Vedic orthodoxy (and orthopraxy), and Śabara and (no doubt) many of his fellow Brahmins did what they could to stop this new trend. With hindsight, it appears that they engaged in a battle for a lost cause: the role of deities worshipped in temples became ever stronger in Brahmanism over time. However, one consequence (if the thesis presented in this paper is correct) is that Brahmanism abandoned its early position regarding the relation between words and things, and removed most of the traces of the earlier situation.

A consequence of this changed philosophical position is visible in the way in which Bhartrhari's Vkp 2.119 came to be interpreted by more recent authors. ${ }^{36}$ Mallavādin's Dvādaśáranayacakra, for example, cites this verse to illustrate that, from a certain point of view, the meaning of the word is unknown. ${ }^{37}$ Simhasūri comments $^{38}$ :

yathā cāhuh: asty arthah sarvaśabdānām iti ślokah. sattāmātram arthah sarvaśabdānām, ko ’py asyārtho 'sti, na nirarthakaḥ śabdah, sa punar artho na nirūpayitum śakyah 'ayam ayam' iti, etat pratyāyyalakṣanam. tatra dṛștānto 'pūrvadevatāsvargaśabdānām arthāh, yathā teșām atyantāparidrștatvāt 'ìdṛ́so 'pūrvah svargo devatā vedrśs' iti na pratipadyāmahe nirūpaṇena tathā

\footnotetext{
35 Willis $(2009$, p. 6) reverses the causality: "gifts to brāhmanas learned in the Veda were sanctioned by tradition, so formalised land-grants were not seen as contentious when they were introduced in the fourth century. Grants to temples, however, were fraught. This was because temple deities were not regarded as 'real' by the Vedic priesthood."

36 See Unebe $(2009,2011)$.

37 DNC I p. 114 1. 1-3: tasmād etasmin nayabhange 'jñāta eva śabdasyārthaḥ. yathāhuh: asty arthaḥ sarvaśabdānām iti pratyāyyalakṣaṇam. apūrvadevatāśabdaih samam āhur gavādiṣu. Cp. Houben (2008, p. 88).

38 DNC I p. 114 1. 9-13.
} 
gavādiśabdānām apy arthais tatsamair eva bhavitavyam, na hi gamanagadanagarjanādiṣv arthavyavasthā viśeșarūpeti 'kaścid asty arthah' ity etâvat pratipattavyam.

"As they say: asty arthah sarvaśabdānām ...". This is a śloka [from Bhartrhhari's Vākyapadīya]. Mere being is the meaning/object of all words. A word has some meaning, it is not without meaning. This meaning cannot however be articulated, [so that one could say] "it is this, or that"; this is the characteristic of what is to be conveyed. An example is [constituted by] the meanings of the words apūrva, devatā and svarga. Just as we do not cognize [their objects] in an articulated manner, [so that we can say] "apūrva is like this, svarga is like this, or devatā is like that", this because they are completely imperceptible, in the same way the meanings/objects of words such as go 'cow' must be similar, for the establishment of the object is not specific with regard to [features that characterize a cow] such as going, lowing and roaring.

All that will be cognized is "there is some meaning/object".

This, as I have argued above, is not Bhartrhari's own interpretation of this kārikā. Rather than the individual, Siṃhasūri (and presumably Mallavādin) look upon "mere being" (sattāmātra; notice the difference from Punyarāja's arthamātra) as the referent of a word.

Unebe $(2009,2011)$ discusses various other Sanskrit authors who interpret Vkp 2.119 in a way that deviates from what we consider Bhartrhari's original intention. One could add various modern translators who do the same. ${ }^{39}$ None of them opt for the simplest and most direct interpretation, and none of them knew (or admitted) that Bhartrhari's kārikā gave expression to a point of view that in the changing times had come to be abandoned, and might have become unimaginable.

\section{References}

Bronkhorst, J. (1987). Mahābhāṣyadīpikā of Bhartṛhari, Fascicule IV, Āhnika I. Poona: Bhandarkar Oriental Research Institute (Post-Graduate and Research Department Series, 28.).

Bronkhorst, J. (1989). Studies on Bharț̣hari, 2: Bhartṛhari and Mīmāṃsā. Studien zur Indologie und Iranistik, 15, 101-117. (Reprinted in Studies in Mīmāmsāa . Dr. Mandan Mishra Felicitation Volume, pp. 371-388, by R. C. Dwivedi, Ed., 1994, Delhi: Motilal Banarsidass.).

Bronkhorst, J. (1992). Quelques axiomes du Vaiśeșika. Les Cahiers de Philosophie, 14 ("L'orient de la pensée: philosophies en Inde"), 95-110.

\footnotetext{
${ }^{39}$ Consider the following translations:

"Jedes Wort hat die Bedeutung 'es ist'; dies ist das Merkmal für das, was begriffen werden soll. Sie nennen es bei Rindern usw. dasselbe wie bei apūrva, devatā und svarga" (Rau 2002, p. 68)

"Existence (asti) is the object (artha) of all words. This is the characteristic of what is to be conveyed (pratyāyya) [by each word]. They say [what is denoted by the words such as] apürva, devatā, and svarga are identical to [what is denoted by words such as] "cow"' (Unebe 2011, p. 537)

"All words have a meaning amounting to: 'something exists'. This meaning is the characteristic of the things denoted by each word. In the case of words like go, they say, it is similar to what is denoted by such words as apürva, devatā and svarga" (Iyer 1977, p. 53)

"'Words all have a (general) meaning' - such a definition of the meaning of the word has been put forth by some, as being applicable as much to words like gauh as to words like apürvam devatā and svargah" (Pillai 1971, p. 65).
} 
Bronkhorst, J. (1997). Philosophy and Vedic exegesis in the Mīmāṃsā. In E. Franco \& K. Preisendanz (Eds.), Beyond orientalism: The work of Wilhelm Halbfass and its impact on Indian and crosscultural studies (pp. 359-371). Poznań Studies in the Philosophy of the Sciences and the Humanities, 59. Amsterdam/Atlanta: Rodopi.

Bronkhorst, J. (2007). Greater Magadha. Studies in the culture of early India. Leiden/Boston: Brill.

Bronkhorst, J. (2011). Language and Reality: On an episode in Indian thought (Translated from the French by M. S. Allen \& R. Raghunathan). Revised and with a new appendix. Leiden/Boston: Brill (Brill's Indological Library, 36).

Deshpande, M. M. (1992). The meaning of nouns: Semantic theory in classical and medieval India. Nāmārtha-nirnaya of Kaundabhatța. Studies of Classical India, 13. Dordrecht: Kluwer.

Frauwallner, E. (1968). Materialien zur ältesten Erkenntnislehre der karmamìmāmsāa. Wien: Hermann Böhlaus Nachf. (Österreichische Akademie der Wissenschaften. Philosophisch-historische Klasse. Sitzungsberichte, 259. Band, 2. Abhandlung. Veröffentlichungen der Kommission für Sprachen und Kulturen Süd- und Ostasiens, Heft 6.).

Hattori, M. (1968). Dignāga, On perception, being the Pratyakșapariccheda of Dignāga's Pramānasamuccaya from the Sanskrit fragments and the Tibetan versions. Harvard Oriental Series, 47. Translated and annotated. Cambridge, MA: Harvard University Press.

Houben, J. E. M. (2008). Doxographic introductions to the philosophical systems: Mallavādin and the grammarians. In W. Slaje (Ed.), Śāstrārambha: Inquiries into the preamble in Sanskrit (pp. 83-95). Abhandlungen für die Kunde des Morgenlandes, 62. Wiesbaden: Harrassowitz.

Iyer, K. A. S. (1977). The Vākyapadīya of Bhartṛhari, Kāṇ̣̂a II. English translation with exegetical notes. Delhi: Motilal Banarsidass.

Jayanta Bhațta Nyāyamañjarī. (Vol. I) (K. S. Varadacharya, Ed.). Mysore: Oriental Research Institute. 1969.

Jha, G. (Trans.) (1933). Śābara-Bhāṣya (3 vols.). Reprint, 1973-1974, Oriental Institute, Baroda.

Lindtner, C. (1982). Nagarjuniana. Studies in the writings and philosophy of Nāgārjuna. Indiske Studier, 4. Copenhagen: Akademisk Forlag.

Nāgārjuna. Vigrahavyāvartan̄i. = Lindtner 1982, 76-86.

Pillai, K. R. (1971). The Vākyapadīya. Critical text of cantos I and II, with English translation, summary of ideas and notes. Delhi: Motilal Banarsidass.

Rau, W. (2002). Bhartṛharis Vākyapadīya. Versuch einer vollständigen deutschen Übersetzung nach der kritischen Edition der Mūla-Kārikās. (O. von Hinüber, Ed.). Mainz: Akademie der Wissenschaften und der Literatur/Stuttgart: Franz Steiner. (Abhandlungen der geistes- und sozialwissenschaftlichen Klasse, Einzelveröffentlichung, 8).

Scharf, P. M. (1990). The denotation of generic terms in Ancient Indian Grammar, Nyāya and Mìmāmsāa . Doctoral dissertation, University of Pennsylvania.

Steinkellner, E. (2005). Dignāga's Pramānasamuccaya, Chapter 1. A hypothetical reconstruction of the Sanskrit text with the help of the two Tibetan translations on the basis of the hitherto known Sanskrit fragments and the linguistic materials gained from Jinendrabuddhi's Ṭîkā. (www.oeaw.ac.at/ias/ Mat/dignaga_PS_1.pdf).

Taber, J. A. (1996). Is verbal testimony a form of inference? Studies in Humanities and Social Sciences, 3 (2), 19-31.

Unebe, T. (2009). Mīmāmsāā and Buddhist criticism on Bhartrhari’s Vākyapadīya 2.119 and his counterarguments. In M. Chaturvedi (Ed.), Bhartrhari: Language, Thought and Reality (Proceedings of the International Seminar Delhi, December 12-14, 2003) (pp. 415-431). Delhi: Motilal Banarsidass.

Unebe, T. (2011). 'Apūrva', 'devatā', and 'svarga': Arguments on words denoting imperceptible objects. Journal of Indian Philosophy, 39(4-5), 535-552.

Willis, M. (2009). The archaeology of Hindu Ritual. Temples and the establishment of the gods. Cambridge: Cambridge University Press. 